\title{
Management of Student Characteristics Through Extracurricular Activities in The School Environment Based on Islamic Boarding Schools
}

\author{
Ujang Sahid ${ }^{1}$, Iim Wasliman ${ }^{2}$, Hendi Suhendraya Muchtar ${ }^{3}$ Husen Saeful Insan $^{3}$ \\ ${ }^{1.2 .3,4}$ Universitas Islam Nusantara Bandung, Indonesia \\ e-mail: zedamanhury@gmail.com
}

Submitted: 04-08-2021 Revised : 09-09-2021 Accepted: 30-10-2021

\begin{abstract}
Moral development is the most important thing in education, including in pesantren-based educational institutions. Moral development will be carried out properly if it is carried out in a planned and programmed manner. Moral Development Management for Students Through Extracurricular Activities in Islamic Boarding Schools is one of the best solutions in realizing commendable student morals. This research was conducted to see the extent to which moral development was carried out at Al-Amin Middle School and Al-Ittihad Middle School Cianjur. The theory that forms the basis of the research is the management theory of POAC, TQM and Six Life Value Systems. This research use desciptive qualitative approach. The research findings show that: (1) The management of the moral development program through extracurricular activities is based on the commitment of teachers, parents, and program implementation. (2) The implementation of the moral development program is the most basic principle and serves as a differentiator for the progress and decline of the quality of SMP. This conformity shows that in practice the moral development program through extracurricular activities has not been carried out according to process standards. (3) Evaluation of activities and problems encountered through monitoring and evaluation of the process and achievement of SMP institution development goals. (4) In general, the inhibiting factors in program development, such as curriculum, budget allocation, facilities and infrastructure. (5) Improvement Efforts, solving problems in quality improvement, one of which is by holding FGD (Focus Group Discussion), workshops, and others.
\end{abstract}

Keywords: Management, Development, Morals, Extracurricular, Pesantren-Based Schools.

https://doi.org/10.31538/munaddhomah.v2i2.97

How to Cite Sahid. U, et al (2021). Management of Student Characteristics Through Extracurricular Activities in The School Environment Based on Islamic Boarding Schools. Munaddhomab: Jurnal Manajemen Pendidikan Islam, Volume (2), 116-125

\section{INTRODUCTION}

Now the Indonesian people are facing educational conditions that tend to experience dynamics of orientation changes related to the expected educational goals. The implementation of competency-based curriculum has succeeded in improving the quality of science and technology, but on the other hand education has neglected the character aspect (Fauzan \& Bahrissalim, 2017; I. Ihsan et al., 2021). "Akhlaq is a reflection of a nation. The measure of educational success is not returned to the character of students (soft skills), but to the achievement of knowledge and skills (hard skills) of students needed by the world of work" (Amri et al., 2019; Berkowitz \& Bier, 2016). So it can be said that education in Indonesia 
prioritizes aspects of knowledge and skills (cognitive and psychomotor/hard skills) rather than character aspects (affective/soft skills).

Islamic boarding schools and schools must be able to synergize and collaborate in instilling noble character. Islamic boarding schools and schools must be able to accommodate them into pesantren-based schools. Pesantren-based formal education institutions must be able to integrate the best programs in the school education system with the provision of education in Islamic boarding schools (Ardiansyah, 2019; M. Hasanah, 2021). According to (Ritzer \& Goodman, 2004) "School-Based Pesantren (SBP) as a model of Islamic education that can combine two social systems, namely the pesantren social system and the school social system". Formal education with Islamic boarding schools aims to make graduates become fully religious as well as scientists, so that they can play a full role in the social system. Pesantren-Based Schools (SBP) are the result of thoughts, discussions between institutions in this case the Ministry of Religion, Ministry of National Education, Center for Educational Development (CERDEV) UIN Syarif Hidayatullah Jakarta, Islamic Boarding Schools, and Schools.

Education is used as an activity to build character for humans. Therefore, appropriate methods are needed according to the abilities and development of students. In educational activities, the most important element that must be implemented is education about noble character (Baharun \& Ummah, 2018; Izfanna \& Hisyam, 2012). This is stated in the Republic of Indonesia Law Number 20 of 2003, precisely in article three concerning the National Education System that "national education aims to develop the potential of students to make people believe, fear God Almighty, have noble character, are healthy, knowledgeable, capable, creative, independent, and become a democratic and responsible citizen.

Seeing the reality that is happening, each of us tends to get more moral education through the non-formal world, or more by giving examples from the older people, which sometimes the older people themselves provide more bad examples (Abdurrahman, 2016; N. Hasanah, 2021). Formal education (schools) or non-formal (Pesantren) is a solution that is needed by the community for the moral education of children. With the hope that when the child enters society he is able to position himself as a human being who can be accepted in various groups or ages, and even further hopes that he will become a respectable human being (Hefner, 2016; M. N. Ihsan et al., 2021).

Responding to the problem of the moral crisis that occurs among young people or students and seeing the existence of Pesantren-Based Schools (BSP) as a model of Islamic education which has the aim of creating human resources who are religious as well as scientists as a whole and have character, it is necessary to manage Islamic Boarding Schools in fostering noble character . Researchers are called upon to conduct research on the Management of Student Moral Development Through Extracurricular Activities in Islamic School-Based Schools with Research Studies at Al-Amin Middle School and Al-Ittihad Middle School, Cianjur Regency. The general objective of this study is to obtain an overview of the management of students' moral development through extracurricular activities in a pesantren-based school environment.

\section{METHOD}

The approach in this study uses a qualitative approach with analytical descriptive method. It is said to be descriptive analytical because the researcher tries to describe the data as it is, then analyze it. Qualitative means that the data analyzed and excavated at the research location are more of the actions (behavior) or words of the research subjects which are more natural than natural settings (Bogdan \& Biklen, 1998). Sources of research data obtained from various stakeholders which include; principal, vice principal of curriculum, students, parents and community. This research was conducted on research objects at Al-Ittihad Middle School and AlAmin Middle School Cianjur which were designated as research locations. Object restrictions are 
based on the criteria of pesantren-based schools in Cianjur district. The data were accommodated using interview, observation, and documentation studies (Creswell, 2007). The data in this study were collected through the following procedures or stages: compiling research instruments, administering permits, exploring the field, selecting and assigning informants, preparing research equipment, conducting simultaneous data collection, checking related to data completeness, and classifying data. To check the validity of the data, the author uses a triangulation technique of data collection techniques. In this technique, the authors cross-check various data from interviews, observations and documentation (Afifudin and Saebani, A. 2009:143). "The data analysis technique uses an inductive approach, this approach is appropriate to use in research with qualitative methods (Lexy J, 2011).

\section{RESULT AND DISCUSSION}

\section{Result}

The results of research in these two pesantren-based secondary education institutions, both at SMP AL Ittihad and SMP Al Amin, in the discussion of the results of this study are an explanation of the relationship between one finding and another, namely aspects of planning findings, organizational aspects, aspects of findings implemented and aspects the findings are assessed, described as follows:

Islamic Boarding School-Based Middle School Management Planning In fostering student morals at AL Ittihad Junior High School and Al Amin Junior High School, from a series of findings at the two institutions, the authors found several steps in their planning, including:

First: In the planning principles of Islamic Boarding School-Based Junior High School in fostering the morals of students at Al Ittihad Junior High School and Al Amin Junior High School DI, it is recommended that the principle is relatively the same, namely to produce students who are creative, innovative, effective, through strengthening attitudes, skills, and knowledge that are integrated in aspects of life. The concept is relatively the same but there are technical differences in lesson planning. Planning at SMP Al Ittihad the structure of the learning device is more detailed by applying the pesantren environment and the yellow book and Arabic and English languages, while at $\mathrm{Al}$ Amin Middle School there is only a pesantren environment and there is no yellow book for Arabic and English.

Second:The purpose of research planning for Islamic boarding school-based junior high schools in fostering students' morals in Cianjur, which was found from these two educational institutions between Al Ittihad and Al Amin Middle Schools, namely to form and develop students' personal potential as a whole in accordance with the Qur'an and Sunnah of the Prophet in a healthy manner in the community with graduates who are ready to serve in the community.

Third: The benefits of planning for a Pesantren-Based Middle School in Fostering the Morals of students in Cianjur, which have been determined by AL Amin Middle School and Al Ittihad Junior High School, it can be concluded that it can be useful especially for themselves (students) in addition to having noble character and having strong skills it is also beneficial for their own parents, especially having good morals and strong knowledge, and useful for the government because especially in the Cianjur district, because recently there have been frequent incidents of violence between students.

Fourth: As for the planning aspects of pesantren-based junior high schools in fostering student morals, which have been determined by these two educational institutions, the aspects studied are related to aspects of planning, organizing, implementing and assessing.

Organization of Islamic Boarding School-Based Middle School Management in Fostering Student Morals. From the findings in the field of Strategic Management Organizing for Islamic 
Boarding School-Based Junior High Schools in fostering student morals at Al Amin Junior High School and Al Ittihad Junior High School from the results of interviews, observations and documentation in this study, there are differences in the organizational structure, namely: First. The organizational structure at SMP Al Amin is shorter, because the structural work area from the head of the school to the teacher is relatively not crowded because there are not many students who are interested in the school compared to SMP Al Ittihad which has thousands of students. Second: In the hierarchy of tasks, the work structure in each institution at SMP Al Amin and SMP Al Ittihad is also slightly different, in SMP Al Amin between the Principal and the Head of the Islamic Boarding School it is a line of instructions, in SMP Al Ittihad it is between the Principal and the Principal. Pesantren is a line of coordination.

\section{Discussion}

\section{Quality oriented}

SMP Al Amin and SMP Al Ittihad essentially refer to the eight educational standards (SNP), content standards, process standards, graduation standards, management standards, facilities and infrastructure standards, financing standards, standards for educators and education personnel and assessment standards, on the other hand. In addition, these two schools also have several changes related to their collaboration with the pesantren curriculum by the principal and the foundation as the organizer, with representatives in the fields of curriculum, student affairs, teaching facilities and in the field of public relations as well as teachers implementing and doing new things for school management. This is in accordance with the concept of change management. According to (Winardi, 2015) is an effort made by managers to make changes effectively and comprehensively with the collaboration of religion or Islamic boarding schools,

\section{Make a change of culture.}

The decision-making for SMP AL Amin and SMP AL Ittihad involves many parties, such as deputy principals, teachers, and school committees from established experts or practitioners.

\section{Carry out organizational changes (upside down organization)}

School management in the field of the AL Amin Junior High School and AL Ittihad Junior High School curriculum has a systematic and realistic learning program that is adapted to the conditions of the school environment and the surrounding environment, each educator designs learning materials and media before the start of the teaching year, each subject teacher describes the current curriculum. this is applied and able to assemble in the analysis of subject matter, each educator designs test questions for learning outcomes in order to help students and improve their administrative system, teaching and learning activities are in accordance with the applicable syllabus, each teacher administers all curriculum activities properly and systematically which leads to behavior and moral development.

\section{Carry out continuous improvement efforts (continuous improvement).}

Planning a learning administration system using computerization which includes several activities in the field of student affairs, including: filing system/correspondence, recording the employee master book, filling in student transfer books, administration of PSB, administration of national exams, increasing student participation in maintaining and fostering schools as wiyata mandalas, so as to avoid influence efforts that are contrary to the rules and norms, create extracurricular activities to support and complement curricular activities.

Learning activities are held on the basis of a planned program, supporting facilities are utilized to maximize existing facilities such as teacher/student toilets by being cleaned every day by students by setting a schedule or cleaned by students who arrive late as punishment, recording assets in the form of educational facilities and infrastructure at SMP AL Amin and SMP AL 
Ittihad by giving the item code, recording and class books, recording in the goods inventory book.

Building teacher awareness (educators) by holding a coordination meeting once a month between school principals, vice principals, teachers and administrative staff that are scheduled outside of incidental special meetings in addition to administration with a computerized approach, applying promotion proposals on a regular basis and by determining based on the number of credits, teacher positions can be completed on time. Educators and coordinators in the field of administration get DP3 on time accompanied by complementary data on the assessment of the employee concerned.

Planning school activities for the next one year period, compiling the program/activity based on type and priority, calculating volume, unit price and funding requirements for each activity component, making working papers and worksheets, planning a budget for funding activities, and pouring it into a format. RAPBS standard, collecting accurate supporting data for reference material in order to maintain the proposed budget.

\section{Maintain good relationship with customers (keeping close to the customer).}

Improving family relations by developing brotherly ties among others which is manifested in social activities and spiritual activities that are carried out a maximum of 5 times a year, improving relations with the community by participating in community activities and social activities such as participating in community service cleaning the bushes that disrupting roads, contributing morally and materially if there is a disaster in the community, for example a death accident. Principals have problems in change management including:

Firstin the results of the decision-making meeting there are still participants who do not comply with or carry out the results of the meeting. second: there are still teachers who do not teach according to the curriculum, delays in collecting learning tools that should be collected at the beginning of the new school year, third: in student management there are still students who are not disciplined and behave according to applicable norms, fourth in the management of educational facilities still the discovery of facilities that are not optimally utilized, such as a laboratory, there are several damaged tools, fifth: in the management of teaching staff there are still teachers who lack awareness and responsibility for their duties, fifth in the management of relations with the community:

This research is a descriptive study, which means that all the data presented will be analyzed by an iterative process. With this standard, the researcher will continue to explore data that is truly in accordance with the research theme. This will have an impact on the time used, this research must be completed for approximately 3 months, and this time is considered effective especially if it still has to clash with school holidays and other big days. Change management according to researchers is a very rare material studied by experts so that researchers still find it difficult to find truly pure references regarding change management. So the author tries to read the references processed by the author to be adapted to the current development of the world of education.

Future improvement steps that need to be taken by the principal as a manager in the school are: 1) Principals and teachers of Pesantren-Based Junior High Schools as technical managers in the classroom, must be able to carry out their respective duties and responsibilities by creating an effective religious program for the implementation of the quality process of Pesantren-Based Junior High School development. 2) School management should continue to develop technical skills, collaboration skills and conceptual skills in order to accommodate all components with an interest in the development of education in schools. 3) The next improvement step is that in his capacity as a leader in schools, school principals should instill religious attitudes, values and norms. Especially in determining the task structure, decision making, application of rewards and 
punishments as well as flexibility in the creation of a program of prospective and innovative school activities. 4) To improve the development of students for achievement, it is necessary to carry out programmed and continuous coaching so that student development programs can be carried out effectively, through planning, organizing and controlling the organization at SMP Plus $\mathrm{Al}$ Amin and SMP Al Ittihad.

Al Ittihad Junior High School and Al Amin Junior High School are general education institutions based on pesantren. Pesantren-based educational institutions still exist even though they are traditional in certain aspects, but can still survive in the midst of modernization. At first the world of Islamic boarding schools seemed unwilling to accept modernization so that there had been a distance between pesantren and the outside world. The long history of our nation's struggle, when other social institutions were not functionally running, pesantren became the center of community activities in religious learning activities, martial arts, treating the sick, and many others. The presence of pesantren in formal education presents a unique and interesting education, not only because of its very long existence, but also because the culture, methods and educational models applied by pesantren are very distinctive.

In this modern era, pesantren has metamorphosed by adopting general knowledge as a form of developing the insight of pesantren residents from an afterlife orientation to being balanced with worldly life. The existence of educational activities between madrasas and public schools, 'live' under the same roof of the pesantren. This means that formal education is carried out in the culture and rules of the pesantren. Thus, the graduates of these schools plus pesantren, apart from being intelligent in terms of general knowledge, are also intelligent in religious knowledge so that they can enter formal schools at a higher level in the national education system (Hokanson \& Karlson, 2013; Yumnah, 2020).

In general, the portrait of a pesantren is a traditional Islamic education dormitory where students live together and study security sciences under the guidance of a teacher who is better known as a kyai. Kyai has a central role in maintaining the tradition and culture of the Islamic boarding school. Islamic boarding schools are categorized into three categories. The pesantren model is: first, the traditional pesantren model which still maintains its salafiyah system, and rejects the curriculum from outside. Until now, this kind of pesantren is still in demand by the community, because a number of pesantren that have been selected by the community have begun to lack culture and morals, so that people look back at the original model of salafiyah education.

The pesantren model which has slightly followed modernization, in this pesantren model, besides accepting the Salafiyah curriculum, this pesantren also accepts the general curriculum. But there are times when social life develops, the character of the pesantren is lost. Also, the original curriculum system was lost, because pesantren were too compliant with the curriculum of the Ministry of Religion or the Ministry of Social Education. Third, pesantren with a model that is in line with the times without eliminating the salafi curriculum. This means that although formal education is general in nature, it is still with the pesantren environment and culture.

For formal education institutions based on pesantren. Of course, pesantren has a different tradition from other institutions. Considering that Pesantren is a religious educational institution (Islam), although it has other functions and is no less important than the function of education. Changes in the dynamic national education system have made people's views on the importance of pesantren-based schools seem bigger from day to day.

The success of Islamic boarding schools in moral education for students, santri or the surrounding community is due to the potential possessed by Islamic boarding schools. These potentials cover three aspects. First, pesantren activities are carried out within 24 hours, both Islamic boarding schools as religious educational institutions, social communities, or as institutions for developing the potential of the people. 
Islamic boarding schools in general have an effect on society, especially rural communities, considering that the majority of Islamic boarding schools are located in areas or rural areas, because it is the demands of the people who want the establishment of Islamic boarding schools. Islamic boarding schools become a belief in religious education for the community. The strong desire of the community to entrust their children's education in boarding schools is of course based on their belief in the guidance carried out by Islamic boarding schools which prioritize religious education (Fakhrurrazi \& Sebgag, 2020; Ma’arif \& Rofiq, 2019).

\section{Practical Analysis}

\section{Potential and Strength}

Thus, based on the results of observations and interviews with principals, vice principals, students and homeroom teachers, it is known that the factors that are strengths, weaknesses, opportunities and challenges in fostering morals are as follows: 1) Led by a principal who has a master's degree in education, he is still quite young and passionate about school progress. 2) Principals regularly conduct evaluations to control the implementation of teacher management. 3) Teachers are generally young, have high spirits and there are still many opportunities to develop their abilities. 4) Cultivating School Culture and Climate is to familiarize the Discipline of Teachers and Students so that it becomes a daily responsibility. Culture and Climate is designed in the form of Teacher and Student Disciplines as well as several real activities such as the Daily Welcoming and Delivering Procession of Students and Congregational Prayers. School culture and climate are also directed at the implementation of Green School Environmental Concepts for both teachers and students. 5) This program is the basis so that every student can follow PBM in SMP Plus Al Amin as a whole, this is because the characteristic curriculum contains lessons: the Qur'an in the form of Qiroah and Tahfidz, Arabic, and routine daily tadarus. This program is delivered with the Al-Qur'an standardization program, which is a special handler for students who have not been able to read the Qur'an with a special method both in PBM and outside PBM at school and at home which is carried out within 3 months and is required as a pre agreement grade promotion. 6) Spiritualization of education is conditioning PBM by always discussing in advance several verses or hadiths related to the subject to be delivered or at least providing examples of Islamic names, events or issues. This program must be supported by all teachers. 7) The individual learning service is an effort so that every student of SMP Plus Al Amin gets optimal service in the teaching and learning process. This service is provided for students who are above average (Smart) and students below average (Underachiever).

Problems and Weaknesses: 1) Facilities and infrastructure are still lacking to support teaching and learning activities. 2) Not all teachers have a bachelor's degree or higher. 3) Teachers have not much experience in education and training to improve their competence. 4) The application of schools has not been directed, it is still in accordance with the understanding of each student. 5) The number of students is still low/few. 6) Less strict teachers against students who are less disciplined. 7) There are not many students who are predicated as champions/achievers in the academic or religious fields. 8) The age gap between teachers and students is short so students often think of teachers as friends (will take teachers lightly). 9) The implementation of HR quality management in schools needs to be improved again. 10) There are still disturbances from outside parties that arise due to teachers leaving school. 11) There is support from the foundation, parents of students so that teachers can carry out learning well. 12) There is support from the District Education Office in developing human resource capabilities through education and training for teachers. 13) The area of the school is still a lot that has not been developed so as to allow more students in the future. 14) Teachers and principals are still young and have great opportunities to develop their abilities. 


\section{Future Trends}

Demands for changes and future trends that the guidance of principals on the process of fostering students that are carried out well have an impact on the process of fostering students' morals and skills in schools which are implemented by good performance, so as to produce quality graduates and quality not only cognitive but also aspects psychomotor and affective that will boost the school's ranking. Therefore, from the quality activities of fostering students through Islamic boarding school-based junior high school teachers into living, growing and developing, their presence will change to achieve goals, and in the future the tendency of SMP Plus Al Amin and SMP Al Ittihad will become schools that excel and compete with other schools.

\section{Anticipatory Steps}

According to researchers, there are some changes that are happening now. First, the role of mothers who have shifted from housewives to career women. This makes the practice of education for children in the family environment is limited and limited by the time that is owned by the mother. Second, a paradigm shift from a materialist paradigm to a spiritualist paradigm for parents in viewing their children. Parents are increasingly aware that children are not only an investment in the world but also an investment in the hereafter. This makes parents want their children to be pious/sholehah generations. Third, the condition of society in the era of globalization is increasingly not insulated. Every foreign influence can appear and develop and even affect the child's behavior. This makes parents want their children to be protected in an educational environment (Alam, 2018; Bashori, 2017).

\section{CONCLUSION}

Based on the results of the research and discussion, a general conclusion was obtained, namely "Management of Moral Development of Students Through Extracurricular Activities in Pesantren-Based School Environments," carried out through the stages of planning, implementation and assessment, this is one of the efforts made to improve the quality of education continuously both in terms of conventional or innovative. This is more focused after it was mandated that the goal of national education is to improve the quality of education at every type and level of education, although in practice there are still many obstacles in the process and especially in the assessment of its many aspects. Meanwhile, the specific conclusions from the results of the research conducted at AL Amin Middle School and AL Ittihad Junior High School are as follows:

The results of the study indicate that the principal as management has carried out the planning carried out by the principal as the school manager. The management functions that are seen are in the form of planning related to Islamic boarding school-based junior high schools, namely work meetings at the beginning of the year that discuss the duties of each teacher, compiling an academic calendar, compiling work programs, developing teacher resources, planning teacher performance appraisals, reward programs and other programs.

Implementation goals and programs moral development of students in Al-Ittihad Middle School and Al-Amin Middle School in Cianjur Regency. Principals at SMP AL Amin and SMP AL Ittihad have been able to demonstrate their existence as schools that have completeness because they have programs and methods that can be seen from the clarity of vision, mission and goals. Then the ability of teachers in implementing the content of the material, process and media as well as evaluating learning has mostly been going well. This is evidenced by the existence of guidelines for preparing annual programs, semester programs, making teaching preparations, learning outcomes evaluation plans and student coaching plans.

Problems faced by teachers in implementing goals and programs moral development of students in Al-Ittihad Middle School and Al-Amin Middle School in Cianjur Regency. Problems 
faced by school principals in developing Islamic boarding school-based junior high schools, teaching schedules, picket schedules and extracurricular schedules, with a measurable standard of assessment the development of teacher human resources will consist of determining the maximum number of teachers who take up training/training, participate in various competitions, teacher performance assessment includes schedules supervision, teacher picket schedule, reward program, debriefing for teachers, providing support to teachers who will continue their education as well as teachers who will attend upgrading/training and other welfare programs.

Future improvement efforts to address problems in the implementation of objectives and programs moral development of students in Al-Ittihad Middle School and Al-Amin Middle School in Cianjur Regency. Principals and teachers of Pesantren-Based Junior High Schools as technical managers in the classroom, must be able to carry out their respective duties and responsibilities by creating an effective religious program for the implementation of the quality process of Pesantren-Based Junior High School development. School management should continue to develop technical skills, collaboration skills and conceptual skills in order to accommodate all components with an interest in the development of education in schools. The next improvement step is that in his capacity as a leader in schools, school principals should instill religious attitudes, values and norms. Particularly in determining the task structure, decision making, application of rewards and punishments as well as flexibility in the creation of prospective and innovative school activities programs. To improve the development of students for achievement, it is necessary to carry out programmed and continuous coaching so that student development programs can be carried out effectively, through planning, organizing and controlling the organization at SMP Plus Al Amin and SMP Al Ittihad..

\section{REFERENCES}

Abdurrahman, N. H. (2016). Character Education in Islamic Boarding School- Based Sma Amanah. Jurnal Pendidikan Islam, 2(2), 287-305. https://doi.org/10.15575/jpi.v2i2.791

Alam, N. A. R. (2018). Strengthening Leadership Culture (The Role of Kyai in Indonesian Pesantren). At-Ta'dib, 13(1), undefined-undefined. https://doi.org/10.21111/attadib.v13i1.1986

Amri, M., Saharuddin, S., \& Ahmad, L. O. I. (2019). The Implementation of Islamic Education: The Process of Instilling Akhlakul Karimah (Noble Characters) for Madrasah Tsanawiyah Students. Tadris: Jurnal Keguruan Dan Ilmu Tarbiyah, 4(1), 117-125. https://doi.org/10.24042/tadris.v4i1.4070

Ardiansyah, M. Z. (2019). Pesantren Hybrid Worldview: Moderatisasi Paradigma Penalaran Keislaman dan Pemenangan Kontestasi Wacana Daring. Jurnal Pendidikan Agama Islam Journal of Islamic Education Studies), 7(1), 1-18. https://doi.org/10.15642/jpai.2019.7.1.118

Baharun, H., \& Ummah, R. (2018). Strengthening Students' Character in Akhlaq Subject Through Problem Based Learning Model. Tadris: Jurnal Keguruan Dan Ilmu Tarbiyah, 3(1), 21-30. https://doi.org/10.24042/tadris.v3i1.2205

Bashori, B. (2017). Modernisasi Lembaga Pendidikan Pesantren Perspektif Azyumardi Azra. Nadwa, 11(2), 269. https://doi.org/10.21580/nw.2017.11.2.1881

Berkowitz, M. W., \& Bier, M. C. (2016). Research-Based Character Education. The Annals of the American Academy of Political and Social Science. https://doi.org/10.1177/0002716203260082

Bogdan, R., \& Biklen, S. K. (1998). Qualitative research for education: An introduction to theory and methods (3rd ed). Allyn and Bacon. 
Creswell, J. W. (2007). Qualitative inquiry \& research design: Choosing among five approaches (2nd ed). Sage Publications.

Fakhrurrazi, F., \& Sebgag, S. (2020). Methods of Learning Kitab Kuning for Beginners in Islamic Boarding School (Dayah). Nað̧hruna: Jurnal Pendidikan Islam, 3(3), 296-310. https://doi.org/10.31538/nzh.v3i3.838

Fauzan, F., \& Bahrissalim, B. (2017). Curriculum Analysis Teacher Professional Education Program (ppg) of Islamic Education in Indonesia. TARBIYA: Journal of Education in Muslim Society, 4(2), 148-161. https://doi.org/10.15408/tjems.v4i2.6400

Hasanah, M. (2021). The Role of Parents in Children Memorizing the Qur'an in Middle School Based on the Amanatul Ummah Islamic Boarding School. Tafkir: Interdisciplinary Journal of Islamic Education, 2(2), 139-156. https://doi.org/10.31538/tijie.v2i2.43

Hasanah, N. (2021). The Role of Madrasah Ibtidaiyah in Building Student Characters in The Era Of The 4.0 Industrial Revolution. Nazhruna: Jurnal Pendidikan Islam, 4(2), 310-319. https://doi.org/10.31538/nzh.v4i2.1304

Hefner, C.-M. (2016). Models of Achievement: Muslim Girls and Religious Authority in a Modernist Islamic Boarding School in Indonesia. Asian Studies Review, 40(4), 564-582. https://doi.org/10.1080/10357823.2016.1229266

Hokanson, B., \& Karlson, R. W. (2013). Borderlands: Developing character strengths for a knowmadic world. On the Horizon, 21(2), 107-113. https://doi.org/10.1108/10748121311323003

Ihsan, I., Pabbajah, M., Abdullah, I., \& Hidayati, H. (2021). The contestation of national and religious curricula in indonesia's madrasas since the passage of the uuspn. Educational Studies, O(0), 1-14. https://doi.org/10.1080/03055698.2021.1958757

Ihsan, M. N., Ahmad, N., Hasanah, A., \& Suhartini, A. (2021). Islamic Boarding School Culture Climate in Forming The Religious Attitude of Islamic Students in Modern and Agrobusiness Islamic Boarding Schools. Naz̧hruna: Jurnal Pendidikan Islam, 4(2), 362-382. https://doi.org/10.31538/nzh.v4i2.1492

Izfanna, D., \& Hisyam, N. A. (2012). A comprehensive approach in developing akhlaq: A case study on the implementation of character education at Pondok Pesantren Darunnajah. Multicultural Education \& Technology Journal, 6(2), 77-86. https://doi.org/10.1108/17504971211236254

Lexy J, M. (2011). Metodologi penelitian Kualitatif (29th ed.). Rosdakarya.

Ma'arif, M. A., \& Rofiq, M. H. (2019). The model of character teacher: Phenomenology at Daruttaqwa Gresik Islamic Boarding School. Attarbiyah: Journal of Islamic Culture and Education, 3(2), 131-152. https://doi.org/10.18326/attarbiyah.v3i2.131-152

Ritzer, G., \& Goodman, D. J. (2004). Modern sociological theory. McGraw-Hill.

Winardi. (2015). Manajemen Perilaku Organisasi. Prenada Media.

Yumnah, S. (2020). Construction of Islamic Boarding Shcool in Developing Moderate Islam. Ną̧hruna: Jurnal Pendidikan Islam, 3(2), 232-246. https://doi.org/10.31538/nzh.v3i2.614 